\title{
研究論文
}

\section{Neptunium-237 in JRR-1 Fuel Solution}

\author{
By Eiko NAKAMURA*
}

The fuel solution of $20 \%$ enriched uranium was taken out from JRR-1 after $5 \times$ $10^{4} \mathrm{kWH}$ operation for chemical analyses. From this solution, neptunium was separated in combination of solvent extraction and anion exchange techniques, providing that ${ }^{237} \mathrm{~Np}$ would be found as the final product of the neutron captures and subsequent beta decay of ${ }^{235} \mathrm{U}$. According to the alpha-spectrometric study, it was shown that the neptunium fraction contained only ${ }^{237} \mathrm{~Np}$.

\section{INTRODUCTION}

Two of the isotopes of neptunium, viz. ${ }^{237} \mathrm{~Np}$ and ${ }^{239} \mathrm{~Np}$, are formed by neutron irradiation of natural uranium as illustrated in Fig. 1. $\quad{ }^{239} \mathrm{~Np}$ is easily obtained by neutron irradiation of natural uranium in the nuclear reactor for few hours and is available for tracer chemical studies of neptunium. ${ }^{237} \mathrm{~Np}$ may be formed through two ways:

(1) from ${ }^{235} \mathrm{U}$ through successive neutron capture via ${ }^{236} \mathrm{U}$, a phenomenon which becomes important in case of enriched nuclearf uels;

(2) by fast neutron reaction on ${ }^{238} \mathrm{U}$ via ${ }^{237} \mathrm{~Np}$.

The long half-lived ${ }^{237} \mathrm{~Np}$ makes macro scale studies of neptunium possible. Therefore, in the course of neptunium study, it was desired to prepare the ${ }^{237} \mathrm{~Np}$ isotope; and this was the first time to identify ${ }^{237} \mathrm{~Np}$ in the JRR-1 fuel solution.

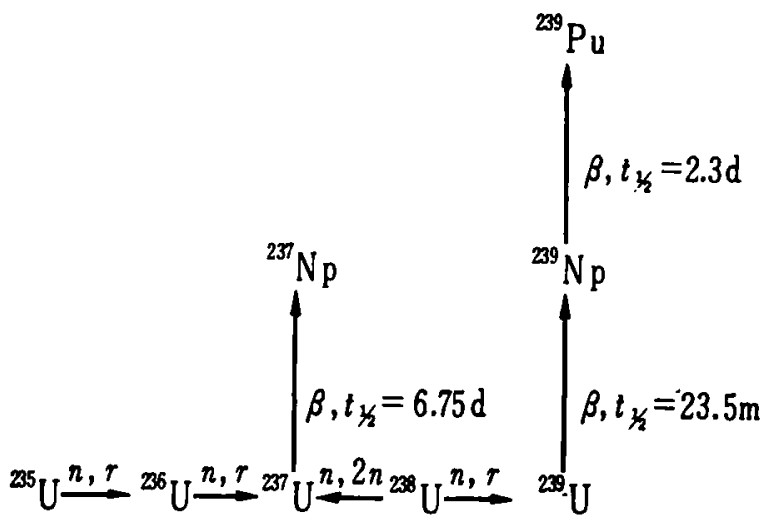

Fig. 1 Formation of ${ }^{237} \mathrm{~Np}$ and ${ }^{239} \mathrm{~Np}$
There are several published works on the isolation of ${ }^{237} \mathrm{~Np}$ from waste solutions of reactor fuel reprocessing ${ }^{(1)-(11)}$. However, in some of these works, neptunium in the starting solution was not recovered completely,

$\frac{\mathrm{Pu}^{+3,4,6}\left(\mathrm{~Np}^{+4,5,6} \mathrm{ppm}\right)}{I}$

( $0.1 \mathrm{M}$ hydroquinone in $12 \mathrm{~N} \mathrm{HCl}$ )
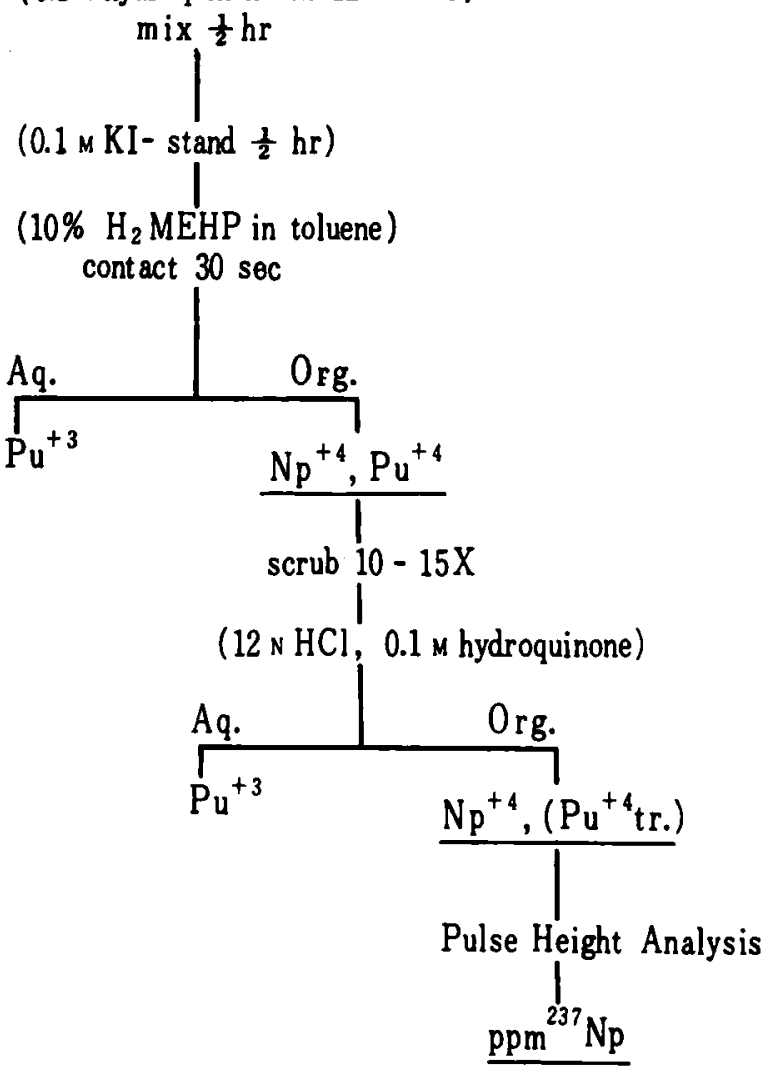

Fig. $2{ }^{237} \mathrm{~Np}$ determination carried out at the ANL

* 中村永子。Chem. Div., Japan Atomic Energy Res. Inst. (日本原子力研究所化学部) 
or the reagent used was thought to be unsuitable. For instance, thenoyltrifluoroacetone was found not so effective when used as separating agent ${ }^{\prime 9}$. In the other works separation was carried out in order to prepare gram quantities of this isotope. Besides the above mentioned works, the process of analysis of neptunium which may contaminate plutonium as developed at the Argonnne National Laborato. ry in U.S.A was reported as Fig. 2. This method involves the use of mono-(2-ethyl hexyl) phosphoric acid as a reagent eor the isolation of ${ }^{237} \mathrm{~Np}$.

In this work, the amount of ${ }^{237} \mathrm{~Np}$ in a little portion of JRR-1 fuel solution was calculated to be very small, about $20 \mathrm{dpm}$, and was present together with large amounts of uranium, plutonium and fission products. Therefore the method for neptunium separation was devised confering with such informations $\tau^{\prime} i=$, the reductants used in the present work were the same as those shown in Fig. 2. Neptunium in aqueous solution shows usually a complicated chemistry having three oxidation states, and it is difficult to prepare neptunium tracer solution which contains only one oxidation state. This fact makes the complete isolation of neptunium, from uranium, plutonium and fission products difficult ${ }^{(9)}$. The isolation method used in this work was based on a previous solvent extraction study (12) in which the TBP (tri- $n$-butyl phosphate) extraction behavior of neptunium in some mineral acids had been investigated, paying particular attention to its oxidation states. Ion exchange studies on nep. tunium ${ }^{13}$ and plutonium ${ }^{14}$ ' having been already carried out in JAERI were also utilized for the isolation of ${ }^{237} \mathrm{~Np}$. The present article describes details of the isolation method of ${ }^{237} \mathrm{~Np}$ using TBP extraction and anion exchange techniques.

\section{Experimental and Results}

\section{Sources of mateirals}

The original solution, a little portion of the fuel solution, was taken out from

$$
\begin{aligned}
& \text { Original Solution } \\
& 20 \mathrm{ml} \text {. } \\
& 1 \mathrm{~N} \mathrm{HNO}_{3} \text {, } \\
& \text { small amount of } \mathrm{H}_{2} \mathrm{SO}_{4} \text {, } \\
& { }^{235,238} \mathrm{U}, 20.5 \mathrm{mg}, \\
& { }^{239} \mathrm{Pu}^{237} \mathrm{~Np}, \\
& \text { F.P. }
\end{aligned}
$$

dried up and converted to chloride

$$
1 \mathrm{~N} \mathrm{HCl} \text { solution }
$$

ascorbic acid

evapolated to nearly dryness

$7.5 \mathrm{NHNO}_{3}$ solution

Dowex - 1 , nitrate from
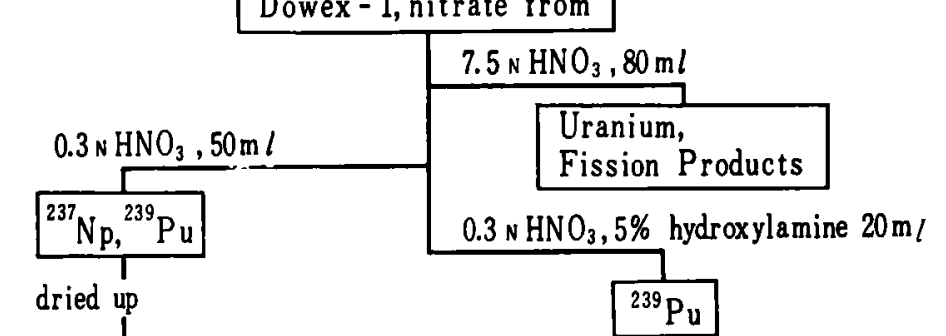

conc. $\mathrm{HClO}_{4}$ solution

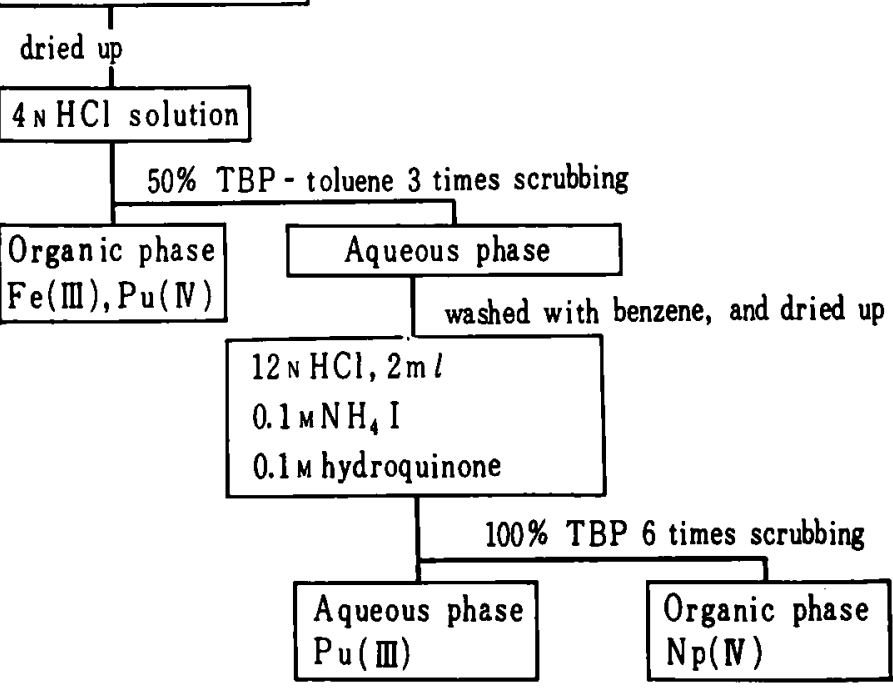

Fig. 3 Process for isolation of ${ }^{237} \mathrm{~Np}$ 
JRR-1 reactor, after attained to the operation time of $2,265 \mathrm{hr}$ with a total power of $5 \times 10^{4}$ $\mathrm{kWH}$. The solution was received after diluting with $1 \mathrm{~N}$ nitric acid. The sample was cooled for 3 months so that ${ }^{239} \mathrm{~Np}$ and short lived fission products might have decay off before separation process was started. The main constituents of the solution are given in Fig. 3.

Both nitric and hydrochloric acids, of analytical reagent grade, were used as received. The reducing agents, ascorbic acid, hydroxylamine hydrochloride, hydroquinone and potassium iodide, were all C. P. grade. Anion exchange resin, Dowex-1, X-8, 100 200 mesh, was used as the nitrate-form after ordinary conditioning. Tri- $n$-butyl phosphate was purified in the usual way ${ }^{(15) \sim(18)}$.

\section{Results}

The process of isolation of ${ }^{237} \mathrm{~Np}$ is schematically shown in Fig. 3. The sample solution was dried up with an infra-red lamp. After being converted to chloride, the obtained residue was dissolved in $1 \mathrm{~N}$ hydrochloric acid. Few milligrams of ascorbic acid were then added the hydrochloric acid solution in order to keep neptunium in the reduced state. The resulted solution was evaporated to nearly dryness avoiding any blackening, and the residue was then taken up in $7.5 \mathrm{~N}$ nitric acid. The nitric acid solution was passed through a Dowex-1 resin column in nitrate form.

As Table 1 shows, ${ }^{237} \mathrm{~Np}$ can not be separately identified from ${ }^{234} \mathrm{U}$, but from ${ }^{235} \mathrm{U}$, ${ }^{236} \mathrm{U},{ }^{238} \mathrm{U}$ and ${ }^{239} \mathrm{Pu}$. Accordingly, the resin column must be sufficiently washed with 7.5 $\mathrm{N}$ nitric acid to remove off uranium completely. Therefore, excessive $7.5 \mathrm{~N}$ nitric acid of $80 \mathrm{ml}$ were passed through the column at this stage.

The gamma activity measured at the outside of the ion exchange column decreased by washing from $150 \mathrm{mr} / \mathrm{hr}$ to $0.15 \mathrm{mr} / \mathrm{hr}$. The combined solution of the effluent and washings was set aside to recover enriched uranium.

The Dowex-1 resin column holding all of neptunium and plutonium was washed
Table 1 Alpha energy of nuclides liable to be present in JRR.1 fuel solution $(\mathrm{MeV})$

\begin{tabular}{ll}
\hline${ }^{234} \mathrm{U}$ & $4.763,4.707$ \\
${ }^{235} \mathrm{U}$ & $4.40,4.58$ \\
${ }^{236} \mathrm{U}$ & 4.499 \\
${ }^{238} \mathrm{U}$ & 4.18 \\
${ }^{237} \mathrm{~Np}$ & 4.77 \\
${ }^{239} \mathrm{Pu}$ & 5.150 \\
\hline
\end{tabular}

with $0.3 \mathrm{~N}$ nitric acid. All neptunium was contained in the initial $50 \mathrm{ml}$ of eluant together with a part of ${ }^{239} \mathrm{Pu}$, which was separated from neptunium in the following step with solvent extraction technique. Besides that, plutonium remaining in the resin column was eluted with $20 \mathrm{ml}$ of $0.3 \mathrm{~N}$ nitric acid which contained $5 \%$ hydroxylamine.

The behavior of neptunium and plutonium in TBP extraction will be surveyed in order to know the conditions in which neptunium is purified effectively from plutonium. The $K_{d}$ values for $\mathrm{Np}(\mathbb{N})$ and $\mathrm{Pu}$ (IV) or $\mathrm{Np}(\mathrm{T})$ and $\mathrm{Pu}(\mathbb{Z})$ in TBP extraction are to be found in some published papers ${ }^{(19) \sim(22)}$, and these oxidation states are thought to be unsuitable for separating these two elements by solvent extraction. The $K_{d}$ values for ${ }^{239} \mathrm{Pu}$, reduced to trivalent state with $0.1 \mathrm{M}$ hydroquinone and $0.1 \mathrm{M}$ ammonium iodide, in the system $100 \%$ TBP vs. hydrochloric acid were determined ${ }^{(19)}$, and the results

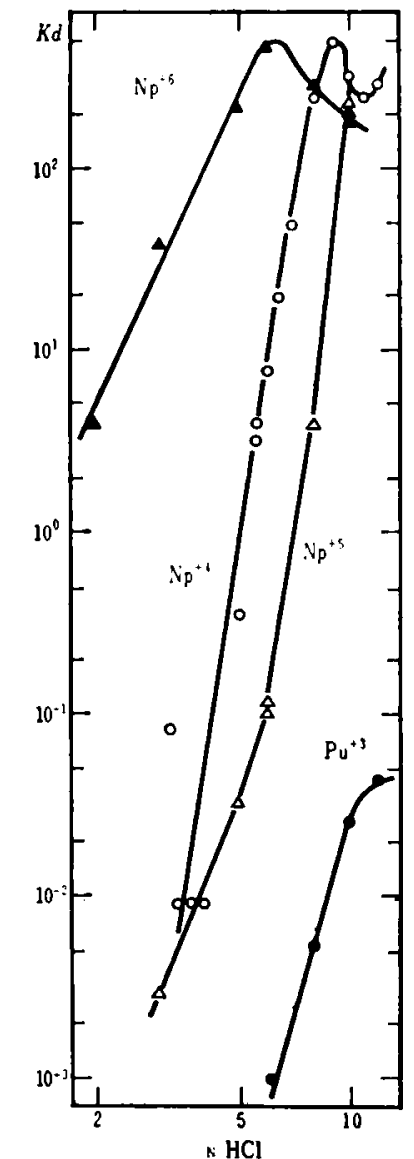

Fig. \& The $K_{d}$ values for $\mathrm{Pu}$ and $\mathrm{Np}$ in the system of $100 \%$ TBP. $\mathrm{HCl}$ 
obtained are plotted in Fig. 4 together with the acid dependence curves for $\mathrm{Np}(\mathbb{V}),(\nabla)$ and (VI) obtained in the previous work ${ }^{(12)}$. From the magnitude of their $K_{d}$ values, $\mathrm{Np}$ $(\mathbb{V})$ and $\mathrm{Pu}(\mathbb{I})$, the two species obtained by the above mentioned reducing agents, can be separated from each other at $12 \mathrm{~N}$ hydrochloric acid. Hence, the purification of ${ }^{237} \mathrm{~Np}$ was carried out according to these informations.

The $0.3 \mathrm{~N} \mathrm{HNO}_{3}$ eluant from Dowex-1 resin column containing ${ }^{237} \mathrm{~Np}$ and a part of ${ }^{239} \mathrm{Pu}$ was brought to dryness. The residue was dissolved in concentrated perchloric acid and was dried up in order to make neptunium in quinquivalent state and iron in trivalent state. After drying up, iron (II) was immediately removed from the $+\mathrm{N}$ hydrochloric acid solution of the residue ${ }^{(15)}$ with $50 \%$ TBP-toluene; a part of plutonium was also extracted into the organic phase. The resulted aqueous phase was washed with benzene and then allowed to dry up. The residue obtained was dissolved in $12 \mathrm{~N}$ hydrochloric acid containing the reducing agents, and neptunium was extracted with the pre-equilibrated $100 \%$ TBP, and then scrubbed 7 times with the same aqueous solution in order to remove plutonium.

Out of the $2 \mathrm{ml}$ organic and the $6.5 \mathrm{ml}$ aqueous solutions resulted, $0.1 \mathrm{~m} l$ portions were plated on platinum plates. The plates obtained gave counts of 130 and $915 \mathrm{cpm}$ of alpha particles respectively with 2 pi gas flow counter, and were sent to St. Paul University,

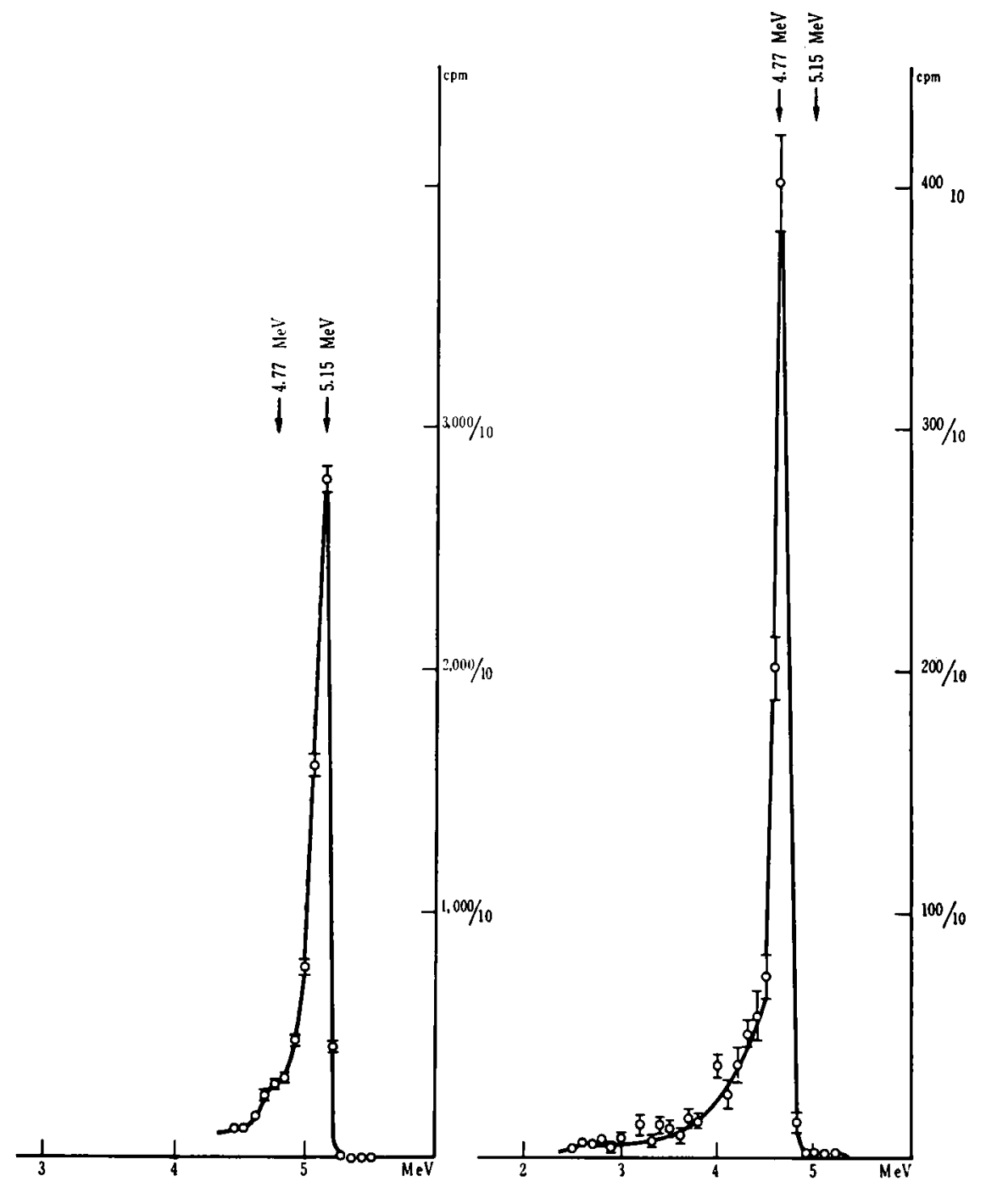

Fig. $5 \alpha$-spectrogram of the last aqueous and organic phase 
Tokyo, in order to assign the particular nuclide by alpha spectrometry. The alpha spectrum of the two phases are shown in Fig. 5. The value of $4.77 \mathrm{MeV}$ was calculated as the alpha energy for the peak measured. Since alpha energy of ${ }^{237} \mathrm{~Np}$ is found to be $4.77 \pm 0.05 \mathrm{MeV}$, the alpha emitter in the organic solution obtained was ${ }^{237} \mathrm{~Np}$. Fig. 5 also shows that no ${ }^{239} \mathrm{Pu}$ was detected in the spectrogram for the isolated ${ }^{237} \mathrm{~Np}$. The purity of ${ }^{237} \mathrm{~Np}$ was high. In the aqueous phase, a very small amount of ${ }^{237} \mathrm{~Np}$ was shown to exist in ${ }^{239} \mathrm{Pu}$; in other words the separation of neptunium from plutonium was fairly good. Finally the amount of ${ }^{237} \mathrm{~Np}$ found in this work was calculated as $10^{2}$ $\mathrm{cpm} / \mathrm{mg} \mathrm{U}$. The gamma and beta activities found in the prepared ${ }^{237} \mathrm{~Np}$ sample was small.

The author wishes to thank $\mathrm{Dr}$. T. Ishimori for his suggestions to this work, $T$. Fujino for his contribution in the determination of $K_{d}$ values for plutonium, and Dr. Prof. T. Dōke for his kindness on the alpha spectrometry.

(Received April 10, 1961)

\section{REFERENCES}

(1) J. S. Nairn, D. A. Collins, H. A. C. McKay, A. G. MADDOCK, B/Conf., P/1458, (1958).

(2) W. H. Lewis: ibid, $\mathrm{P} / 537$, (1958).

(3) H. B. Evans, W. B. Seefeldt, H. H. Hyman: ANL-4442, (1950).

(4) L. B. Magnusson, T. J. LaChapelle: J. Am. Chem. Soc., 70, 3534 (1948).

(5) J.S. NAiRn, D. A. Collins: "Progress in Nuclear Energy", Series III, Process Chemistry, Vol. 2, (1958), Pergamon Press, London.

(6) J. R. Flanary, G. W. Parker : ibid., (1958).

(7) J. R. Flanary, J. H. Goode, R. G. MansFIELD, R. P. WiSCOW: ORNL-2235, (1957).

(8) J. R. Flanary, J. H. GOODE : Ind. Engng. Chem., 51, 55 (1959).

(9) L. B. Magnusson, J. C. Hindman, T. J. La-
Chapelle: $A N L \cdot 4066$, (1947).

(10) E. HESFORD, H. A. C. MCKAY: $A E R E-C / R$ 1893, (1956).

(11) G. Johansson: Svensk. Kem. Tidskr., 65, 79 (1953).

(12) T. Ishimori, E NaKamura: Bull. Chem. Soc. Japan, 32, 713 (1959).

(13) F. ICHIKAWA: ibid., 31, 778 (1958).

(14) K. Kimura, T. Ishimori, K. Naito, H. Umezawa, K. WATANABE: This Journal, 2, 328 (1960).

(15) T. Ishimori, K. Watanabe, E. Nakamura: Bull. Chem. Soc. Japan, 33, 636 (1960).

(16) K. Alcock, S. S. Grimley, T. V. Healy, J. Kennedy, H. A.C. McKay: Trans. Faraday Soc., 52, 39 (1956).

(17) D. F. Peppard, G. W. Mason, J. L. Maier : J. Inorg. Nucl. Chem., 3, 215 (1956)

(18) D. F. Peppard, W. J. Driscoll, R. J. SiroNEN, S. MCCARTY: ibid., 4. 326 (1957).

(19) T. FUנINo: unpublished

(20) H. A. C. McKay, J. S. Nairn, M. B. WaldRON: B/Conf., P/304, (1958).

(21) H. A. C. McKaY: A/Conf., 7. P/441, (1956), United Nations Publ., New York.

(22) G. F. BEst, H. A. C. MCKay, P. R. WOODGATE: J. Inorg. Nucl. Chem., 4, 315 (1957).

\section{JRR-1 燃料中のネプツニウム -237}

$$
\text { 中 村 永子 }
$$

総合調查の目的で一部分取り出されたJRR-1の燃 料中には，長寿命の $\alpha$ 放射体である同位体の存在が予

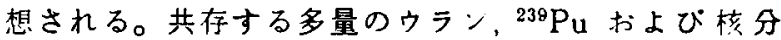
裂生成物からネプッニウムを分離精製し， ${ }^{237} \mathrm{~Np}$ の存 在を確認した。

陰イオン交換および溶媒抽出について，すでに得ら れているデータを基整とし、プルトニウムについての データを一部補足して分蜼精製法を計画した。

得られたネプッニウムのフラクションについて， $\alpha$

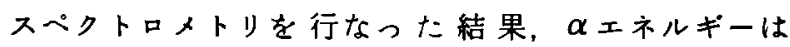
${ }^{237} \mathrm{~Np}$ に一致した。得られた量は $10^{2} \mathrm{cpm} / \mathrm{mgU}$ であ り， $\beta, \gamma$ 放射体の量は少就った。 